\title{
Does inflation or currency depreciation drive monetary policy in Russia?
}

\author{
Brigitte Granville $^{\mathrm{a}, *}$, Sushanta Mallick ${ }^{\mathrm{b}}$ \\ a Centre for Business Management, Queen Mary, University of London, Mile End Road, London E1 4NS, UK \\ ${ }^{\mathrm{b}}$ Department of Economics, Loughborough University, Ashby Road, Loughborough, \\ Leicestershire LE11 3TU, UK
}

Received 31 January 2005; received in revised form 5 April 2005; accepted 1 September 2005

Available online 10 October 2005

\begin{abstract}
This paper analyses the persistence of inflation in post-communist Russia, with interest rate, exchange rate, and money supply as key arguments. The paper then derives a monetary policy feedback rule, which has been used to show empirically in the context of Russia that the official interest rate has reacted more to exchange rate changes than reacting to inflation, thereby keeping inflation as a persistent problem. This implies a need to have a 'flexible targeting rule' for inflation so as to bring it under control, which would make interest rate as a key monetary policy instrument for price stability.

(C) 2005 Elsevier B.V. All rights reserved.
\end{abstract}

JEL classification: C13; E43; E58; P24; P34

Keywords: Monetary policy reaction function; Exchange rate; Fisher relation; Inflation; Interest rate; Russia

\section{Introduction}

The Russian economy has experienced dramatic economic events since the dismantlement of the Soviet Union. Those events have led to periods of very high and volatile inflation rates followed by successive stabilizations. For such an interesting economic environment the question as to what determined the central bank's policy arises naturally.

The central bank of a matured economy can be expected to use interest rates to regulate the inflation rate. In early Russia, the absence of an effective monetary policy framework was due not

\footnotetext{
* Corresponding author. Tel.: +44 207882 7446; fax: +44 2078823615 .

E-mail addresses: b.granville@qmul.ac.uk (B. Granville), s.k.mallick@lboro.ac.uk (S. Mallick).
} 
only to the challenge of establishing new institutions and regulations, but especially also to the difficulty of overcoming the legacy of central planning where budget and credit financing were indistinguishable. ${ }^{1}$ The role of the central bank was not well defined. During certain periods, the central bank acted as the banker of the government providing liquidity without consideration for the financial markets. During other periods, its action focussed on the financial markets to provide a restrictive monetary policy or to provide funds to a weak financial industry. In any of these cases one can expect a disconnection between inflation and interest rates.

Post-communist Russia's monetary policy has passed through two monetary regimes: a money based programme was used from July 1992 to June 1995 and September 1998 to the present (February 2005) ${ }^{2}$ an exchange rate based stabilisation programme was used in the period from July 1995 to August 1998. Behind these variations in the policy regime lies a continuity in the tension between price and exchange rate stability. A common factor can be discerned underlying this tension. This factor is the authorities' use of macroeconomic policy as a direct instrument of social welfare provision. In the period through to the August 1998 crisis, this phenomenon took the form of a lack of fiscal adjustment, in turn generating heavy budget deficit financing requirements. The subsequent period has seen sustained budget surpluses (since 2000) due to fiscal discipline rather than to the strength of the oil price. ${ }^{3}$ High world oil prices have widened the balance of payments surplus. The monetary authorities have been pulled between the goal of reducing inflation and the goal of restraining the real exchange rate appreciation resulting from the balance of payments surplus in order to shelter domestic employment from import competition. The Bank of Russia seems to have preferred slowing the real exchange rate appreciation rather than the rate of inflation, as a result inflation proxied by the consumer price index changes has stayed quite high reaching 11.7 percent in 2004 compared with 12 percent in 2003 , exceeded a government target of 8 percent to 10 percent.

To remedy the conflict taking place between price stability and currency appreciation, this paper recommends a move to inflation targeting that may give more control over price stability to the Central Bank while reducing its interventions in the foreign exchange market. ${ }^{4}$ Other economies in transition such as the Czech Republic, Poland and Hungary have adopted inflation targeting for reasons of joining the EMU. ${ }^{5}$ Our contribution here is to analyze Russian inflation dynamics and monetary policy suggesting that adopting inflation targeting could help the Central Bank of Russia to reduce the tension between the exchange rate and the monetary policy.

The paper is organised as follows. In Section 2, we present the state of the monetary and exchange rate policies in Russia, with a model, deriving optimal interest rate rule in Section 3. The data, and the empirical results are presented in Section 4. The study of the time series behaviour and the search for a possible relation between interest rate, inflation rate, exchange rate and real money growth is expected to indicate what type of policy has been followed by the central bank. It has been found for Western type economies that inflation and interest rates are integrated processes. ${ }^{6}$ Integrated processes have a long memory, meaning that any change to the current level of inflation will have a permanent effect. If series are integrated then tests for integration and

\footnotetext{
${ }^{1}$ See Granville (2003).

2 Since February 1, 2005, the Bank of Russia is using a basket consisting of $€ 0.1$ and $\$ 0.9$.

3 See OECD (2004), p. 7.

${ }^{4}$ See Bernanke et al. (1999) for a review on the pros and cons of inflation targeting.

5 Orlowski (2000); Jonas and Mishkin (2003).

${ }^{6}$ Barsky (1987); Crowder and Hoffman (1996); Mishkin (1992); Evans and Lewis (1995).
} 
co-integration have to be used. Further interesting dynamic behaviour can be established through an error correction mechanism. Section 5 concludes the paper.

\section{Monetary and exchange rate policies in Russia}

Post Soviet Russia started with the legacy of a high ratio of debt service to fiscal revenues. Monetary independence was achieved in July 1993, following the abandonment of the ruble zone. $^{7} 1992$ to mid-1995 saw large budget deficits being initially financed by money creation leading to high and volatile inflation rates. Studies on Russia's 1990s high inflation include Buch (1998), Korhonen (1998) and Nikolic (2000). The average real interest rate was negative. Investors faced a choice between holding their liquidity in cash and bearing the full burden of inflation, or investing it in foreign exchange or short-term treasury bills. The domestic bond market was introduced in May 1993, with foreign borrowing being unavailable due to the 1991 debt default. Cotarelli and Doyle (1999) illustrate how the financing of budget deficit - whether by seigniorage or by domestic debt issuance - constrained monetary policy. Granville (2001) examined Russia's monetary policy both historically and analytically by focussing on the balance sheet of the central bank and showed that after mid-1993, credits to governments (that is explicit monetary financing of the budget deficit) became the main source of domestic asset growth and the main cause of high inflation.

From about June 1995 to the financial crisis of August 1998, the switch to an exchange rate stabilisation programme and to bond-financing marked the beginning of relatively low average monthly inflation compared to the previous sub-period (1.85\% compared with $13.18 \%)$. But financing the budget deficit through bond rather than money creation meant that public debt grew rapidly given the negative or low rates of real GDP growth. During 1995-1998, the real interest rate was positive. In 1995, t-bill issues financed over half of the federal deficit, and by the end of 1996 the t-bill market accounted for almost half of total Russian domestic public debt. T-bill yields were very high and volatile reaching monthly rates of 12 percent before the first round of the presidential election in April 1996 and decreased to below 3 percent at the end of 1996. Throughout 1996, the government's need to refinance its debt and the decline in tax collection meant that to reduce t-bills yields over the medium term meant attracting foreigners into the t-bill market. As a result the CBR partially liberalized the t-bill market in August 1996. Towards the end of 1997, when Asian banks suffered losses on lending at home, they sold their holdings of Russian high-yielding bonds to improve their liquidity positions, putting pressure on the rouble and on the bond market. The central bank sought to defend the rouble by raising the refinance rate and allow interest rates to move to whatever level was necessary for the exchange rate to be maintained within the band. The refinance rate acted as an effective cap on the t-bill yield and so signalled the level at which the CBR would support the price. The refinance rate was raised first in mid-November 1997 from 21 percent to 28 percent. In February 1998, it was increased to 42 percent and in May 1998 to 150 percent. Such high interest rates, however, were fiscally unsustainable and on August 17, 1998 the Russian authorities announced the domestic debt default and devaluation of the domestic currency (followed shortly by the abandonment of the exchange rate target band). ${ }^{8}$ Desai (2000) analyses the factors that led to the 1998 crash and argues that it resulted from exogeneous factors such as the decline in oil and nonferrous metal prices interacting with fiscal policy weaknesses. Komulainen and Pirtilla (2000), by examining

\footnotetext{
7 See Granville (2002).

${ }^{8}$ Granville (2001); Kharas et al. (2001).
} 
an unstructural vector-autoregressive model of prices, exchange rate, money and fiscal balance for Russia, find that fiscal balance does not cause movements in the price series using the Granger test. The authors showed a large effect from exchange rate to prices possibly explained by the role of the exchange rate in inflation expectations. Basdevant and Hall (2002) within a simulation exercise show that exchange rate expectations played a key role in the origin of the August 1998 financial crisis.

Following the August 1998 events, the 12 month inflation was 84 percent in December 1998, real interest rates were negative, monetary financing of the budget deficit resumed as both domestic and foreign borrowing were unavailable. Another source of money supply growth was the partial bail-out of the domestic banking system following its bankruptcies after devaluation. But "surprising everyone, the crisis became a positive turning point". 9 From the beginning of 1999 the fiscal situation started to improve due to a radical change in macroeconomic policy. Inflation was once again determined by exchange rate policy rather than fiscal policy - although the policy environment was now radically different, as the authorities ran budget surpluses (which, for the enlarged government, averaged 2\% of GDP annually in the years 2000-2003). As a result, budget surpluses were able to blunt the inflationary impact of exchange rate targeting by sterilizing some of the money created to restrain the real effective appreciation of the rouble exchange rate. This restraint produced continued nominal depreciation of the rouble - despite large external surpluses - until as late as 4Q03. The immediate impact of devaluation is inflation, as many intermediate and final goods are imported.

In the post-1998 period, the dilemma Russia has faced is high global oil prices improving fiscal balance, but generating serious problems for monetary and exchange rate policies. This in turn compels the Central Bank to buy excess foreign exchange from the market, thereby expanding the money supply and generating inflation. On the contrary, if the Central Bank decided not to intervene in the foreign exchange market, this would have resulted in nominal appreciation of the rouble. In short, on the one hand, there is high inflation, and on the other hand, there is high currency appreciation. Thus, there is a tension between the policy objectives of stabilising the exchange rate or inflation. To resolve this tension, the policy challenge therefore is to design an optimal monetary policy, as a flexible targeting rule giving weights to both policy objectives.

\section{A model for the CBR's monetary policy reaction function}

The monetary authority - Central Bank of Russia (CBR) - does not communicate a policy on inflation to private economic agents. Therefore, we first look at how the agents set their expectations about inflation. As we consider price formation in the context of an open economy, the exchange rate will affect the money market equilibrium along with the preference of the authorities. With a flexible exchange rate regime, currency fluctuations will influence the conduct of monetary policy. Thus, the level of real output $(y)$, expected inflation $\left(\pi^{\mathrm{e}}\right)$, interest rate $(i)$ and exchange rate $(e)$ can therefore determine the real money balances $(M / P=m)$. The money market equilibrium to represent the demand side can be shown via an open economy LM function as follows:

$$
m_{t}=\theta y_{t}-\beta\left(i-\pi^{\mathrm{e}}\right)_{t}-\delta e_{t}
$$

where the coefficients are all positive.

\footnotetext{
${ }^{9}$ Pinto et al. (2004): 2.
} 
In this model, the depreciation of the exchange rate reflects the fact that domestic residents may also hold foreign currency for transactions or precautionary purposes in the presence of domestic inflation (Papazoglou and Pentecost, 2004). This means domestic currency depreciation may lead to a decline in real money balances encouraging currency substitution. The situation where real money balances are influenced by expected inflation is partly in line with a Cagan style relation under conditions of hyper inflation (see, for example, Taylor, 1991; Frenkel and Taylor, 1993) which also include currency depreciation in the estimation of the money demand function for high inflation countries). Choudhry (1998) also found that the rate of change of the exchange rate needs to be included in the demand function for real $M 2$ to obtain a stationary long-run relationship.

If uncovered interest rate parity (UIP) holds reflecting the assumption of perfect capital mobility, then it suggests a link between $i$ and $e$ equating the expected return on domestic and foreign assets:

$$
e_{t}=e_{t+1}+\left(i^{*}-i_{t}\right)
$$

where $i^{*}$ represents foreign interest rate.

The aggregate supply equation can be formulated following a traditional open-economy Phillips curve as follows:

$$
\pi_{t}=\pi_{t}^{\mathrm{e}}+\lambda y_{t}+\phi e_{t}
$$

where the coefficients $\lambda$ and $\phi$ are greater than zero.

Given the use of the US dollar in many transactions, any change in the exchange rate has a direct effect on prices. Here, it is assumed that the policy-maker aims to minimize deviations from specified targets for inflation and exchange rate, formally represented by the loss function $(L){ }^{10}$

$$
L=\omega\left(\pi-\pi^{*}\right)^{2}+\mu\left(e-e^{*}\right)^{2}
$$

with $\omega>0$ and $\mu>0$.

As we have considered the exchange rate as one of the variables in the loss function, the specification is most appropriate in the context of Russia. We assume that the central bank minimizes its loss with inflation and exchange rate deviations from their targets and determines the interest rate. Interest rate is reduced to discourage currency appreciation, but it creates inflation, via monetary expansion, hence establishing a trade-off between the exchange rate and inflation. As the exchange rate stabilisation is one of the objectives of the central bank, then the exchange rate can be included as a determining factor in the central bank's reaction function, as suggested by Taylor (2001).

This calls for a flexible targeting rule which assigns weights to both the policy targets. The targeted exchange rate can be implicitly assumed to be in line with potential output level.

Rewriting Eq. (1) for $y$ and substituting it in Eq. (3), we get:

$$
\pi_{t}=\pi_{t}^{\mathrm{e}}+\frac{\lambda}{\theta} m_{t}+\beta \lambda\left(i-\pi^{\mathrm{e}}\right)_{t}+(\delta \lambda+\phi) e_{t}
$$

Substituting (5) and (2) in (4), we minimize the loss function with respect to exchange rate, because the central bank tries to monitor the exchange rate to keep it stable. The following

\footnotetext{
${ }^{10}$ For a commonly used loss function with inflation and output to explain the central bank behaviour, see Barro and Gordon (1983); Clarida et al. (1999).
} 
expression can therefore be obtained from the first order condition with respect to the exchange rate:

$$
\begin{aligned}
\frac{\partial L}{\partial e}= & 2 \omega\left(\pi^{\mathrm{e}}+\frac{\lambda}{\theta} m+\beta \lambda\left(i-\pi^{\mathrm{e}}\right)+(\delta \lambda+\phi) e-\pi^{*}\right) \\
& \times(\delta \lambda+\phi)+2 \mu\left(e_{t+1}+i^{*}-i-e^{*}\right)=0
\end{aligned}
$$

Assuming that the monetary authority maintains exchange rate stability, we can solve the above expression for the corresponding interest rate policy. The authorities' targeted inflation $\left(\pi^{*}\right)$ can be normalized to be zero, as there is no inflation targeting in Russia, and actual inflation might be in line with the expected inflation $\left(\pi^{\mathrm{e}}\right)$ of private agents. Thus we assume that $\pi^{\mathrm{e}}=\pi$, and for simplicity $e_{t+1}=e_{t}$. Thus, the monetary policy reaction function or the interest rate rule can be derived from the above expression as follows:

$$
\begin{aligned}
i_{t}= & \frac{\mu i^{*}}{\mu-\omega \beta \lambda(\delta \lambda+\phi)}+\frac{\omega(\delta \lambda+\phi)(1-\beta \lambda)}{\mu-\omega \beta \lambda(\delta \lambda+\phi)} \pi_{t}+\frac{\omega(\delta \lambda+\phi)^{2}}{\mu-\omega \beta \lambda(\delta \lambda+\phi)} e_{t} \\
& +\frac{\lambda \omega(\delta \lambda+\phi)}{\mu-\omega \beta \lambda(\delta \lambda+\phi)} m_{t}
\end{aligned}
$$

Eq. (6) can be rewritten as follows:

$$
i_{t}=\alpha_{1}+\alpha_{2} \pi_{t}+\alpha_{3} e_{t}+\alpha_{4} m_{t}
$$

where

$$
\begin{aligned}
& \alpha_{1}=\frac{\mu i^{*}}{\mu-\omega \beta \lambda(\delta \lambda+\phi)} \\
& \alpha_{2}=\frac{\omega(\delta \lambda+\phi)(1-\beta \lambda)}{\mu-\omega \beta \lambda(\delta \lambda+\phi)} \\
& \alpha_{3}=\frac{\omega(\delta \lambda+\phi)^{2}}{\mu-\omega \beta \lambda(\delta \lambda+\phi)} \\
& \alpha_{4}=\frac{\lambda \omega(\delta \lambda+\phi)}{\mu-\omega \beta \lambda(\delta \lambda+\phi)}
\end{aligned}
$$

This reduced form optimal reaction function suggests first that as inflation increases the interest rate increases, supporting a theoretical Fisher relation, and secondly that the interest rate increases in line with real money, and as the exchange rate is defined as the domestic currency price of a foreign currency, any depreciation in the exchange rate will be reflected in a rise in the interest rate.

The model needs to be tested as regards the question of whether the interest rate has reacted more to exchange rate changes or inflation. If it is the former, then it can be proved that the current monetary policy stance of the central bank is not primarily designed for price stability. For the model to be consistent with the closed economy Taylor rule, the coefficient of inflation should be larger than one. In the central bank's loss function, if $\mu>0$, such preferences are defined as a policy of "flexible inflation targeting", if $\mu=0$, it can describe a case of "strict inflation targeting" or an "inflation nutter" (Svensson, 1999). 


\section{Data and empirical results}

Any attempt to model the Russian economy is constrained by the reality of a low-quality and limited data set (see, for example, Basdevant, 2000, who modelled the real side of the economy). Our focus in this paper is on the monetary side of the economy. Given the data limitations, we do not intend to look at the interaction between the real and monetary sectors. We use data at a monthly frequency between February 1992 and January 2005 (we start in February 1992 to avoid the huge price jump of over $240 \%$ due to the monetary overhang following price liberalisation). Monthly observations on the seasonally unadjusted consumer price index, CPI (a Laspeyres index), were collected as reported by the Russian State Statistics Committee (Goskomstat, 1992-2004). ${ }^{11}$ The data were de-seasonalised using the US Census Bureau's X12 seasonal adjustment programme. The seasonally adjusted price data, CPI, were transformed into monthly inflation rates $\pi_{t}$ in percentage terms using:

$$
\pi_{t}=\log \left(\frac{\mathrm{CPI}_{t}}{\mathrm{CPI}_{t-1}}\right) \times 100 .
$$

The nominal monthly exchange rate (end of the month), erateend, is reported by the Central Bank. The end of the month exchange rate is transformed into monthly exchange rate changes $e_{t}$ in percentage terms using:

$$
e_{t}=\log \left(\frac{\text { erateend }}{\text { erateend }_{t-1}}\right) \times 100 .
$$

We use the refinancing rate (i.e. the discount rate) (REFRATEM) as the official interest rate, which the central bank changes to respond to the changes in macroeconomic variables and we call it $i_{t}$. The $M 2$ aggregate is the volume of cash in circulation (outside the banks) and balances in national currency in the settlement in current accounts and deposits of resident non-financial enterprises, organisations and individuals. It does not include foreign currency deposits. ${ }^{12}$ Since January 1, 1998, money supply does not include data on credit institutions which have had their licence recalled. To make it possible to analyse and compare the money supply data with previously published ones, the dynamic series of these indicators are calculated without the data of credit institutions which revoked licence and according to the former methodology over a maximum possible period of availability of such information. Both $M 2$ and the refinance rate are reported by the central bank of Russia web site. In order to obtain real money balances (rm) changes the $M 2$ data have been transformed in percentage terms using:

$$
\mathrm{rm}=\log \left(\frac{(M 2 / \mathrm{CPI})_{t}}{(M 2 / \mathrm{CPI})_{t-1}}\right) \times 100 .
$$

Fig. 1 plots the monthly inflation, the refinance rate, the rate of nominal exchange rate depreciation at the end of the month and real balances changes. The data seem to reveal significant changes of the dynamics over time. The monthly rate of inflation in the Russian consumer price index since January 1992 marks price liberalisation. For the period 1992-1998, the average monthly inflation rate reached 41 percent in 1992 (due to the price jump of over 200 percent in January 1992

\footnotetext{
${ }^{11}$ Goskomstat is the state agency gathering and publishing data for the Russian economy. Goskomstat stopped publishing weekly inflation rates in January 1997, fear of hyperinflation after the August 1998 financial crisis saw the weekly figures publish for a short while and since then only monthly rates are available.

12 See Kwon et al. (2004) for a discussion on money demand in Russia and how the inclusion of the foreign cash holdings in the definition of money improves the stability of the money demand function.
} 

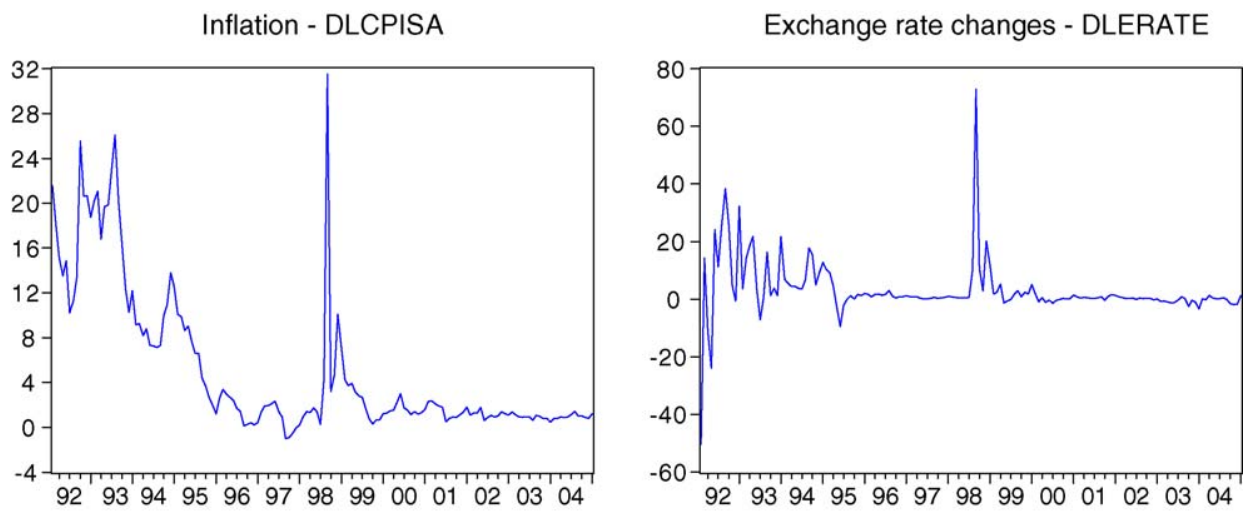

Real money changes - DLRM

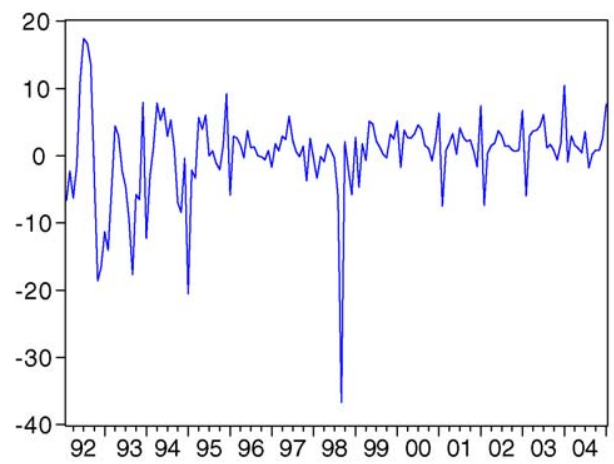

Refinance rate - REFRATEM

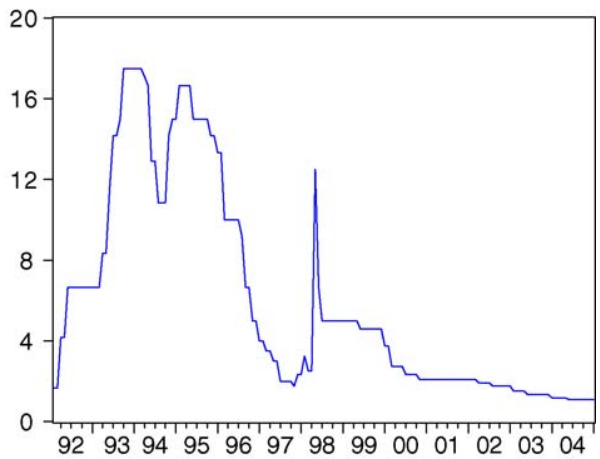

Fig. 1. Inflation, refinance rate, nominal exchange rate and real balances changes in percent, February 1992-January 2005 .

following the price liberalization and 18 percent without the January observation), 21 percent in 1993, 10 percent in 1994, 7 percent in 1995. The year 1996 marked the first average monthly inflation rate below 2 percent with 1.7 percent, followed in 1997 with a rate of 0.9 percent and 0.6 percent from January 1998 to July 1998.

We notice that for the period between February 1992 and April 1995 the average ex post real interest rate is negative. This situation occurred because the inflation rate rose to high levels and even though investors could place their savings into foreign exchange deposits such deposits were risky. A rational alternative was to leave a certain amount in the t-bills market but the amount of such investment remained small. The picture is reversed between May 1995 and July 1998 where the ex-post real interest rate was constantly positive and even very high. It is likely that the government used t-bills to help provide liquidity to the financial market.

Summary statistics for the data are displayed in the upper panel of Table 1. The data displays evidence of non-normality with all series displaying statistically significant skewness and excess kurtosis. Moreover, the hypothesis of normal distribution seems to be rejected at all levels of significance.

A necessary but not sufficient condition for cointegration is that each of the variables should be integrated of the same order (more than 0 ) or that both series should contain a deterministic trend (see Granger, 1986). The test results are also reported in Table 1. 
Table 1

Summary statistics

\begin{tabular}{|c|c|c|c|c|c|}
\hline & Mean & S.D. & Skew & E. Kurt & Normality \\
\hline$\pi_{t}$ & 5.1601 & 6.6602 & 1.6855 & 2.0879 & $\begin{array}{l}199.5 \\
{[0.0000]}\end{array}$ \\
\hline$i_{t}$ & 5.9995 & 5.2294 & 1.0049 & -0.4188 & $\begin{array}{c}120.181 \\
{[0.0000]}\end{array}$ \\
\hline$e_{t}$ & 3.4247 & 9.2080 & 3.5994 & 21.524 & $\begin{array}{l}247.07 \\
{[0.0000]}\end{array}$ \\
\hline $\mathrm{rm}_{t}$ & 0.1272 & 5.8171 & -1.2195 & 4.1142 & $\begin{array}{l}28.476 \\
{[0.0000]}\end{array}$ \\
\hline
\end{tabular}

ADF Unit Root tests

\begin{tabular}{lrrr} 
& $\operatorname{ADF}(\tau)$ & $\operatorname{ADF}(\mu)$ & ADF \\
\hline$\pi_{t}$ & -2.8047 & -2.31979 & -2.2356 \\
$i_{t}$ & -3.0982 & -1.4552 & -0.9853 \\
$e_{t}$ & -11.6756 & -10.6620 & -4.1594 \\
$\mathrm{rm}_{t}$ & -8.7144 & -8.3783 & -8.3984 \\
$5 \%$ & -3.4390 & -2.8800 & -1.9429
\end{tabular}

Elliot, Rothenberg and Stock tests

KPSS tests

\begin{tabular}{llllrll} 
& DFGLS $(\tau)$ & DFGLS $(\mu)$ & $P(\tau)$ & $P(\mu)$ & $\eta_{\tau}$ & $\eta_{\mu}$ \\
\hline$\pi_{t}$ & -2.0923 & -0.4478 & 11.2070 & 24.1580 & 0.2612 & 0.9811 \\
$i_{t}$ & -1.4430 & -1.2483 & 28.9996 & 8.5530 & 0.1047 & 0.9814 \\
$e_{t}$ & -1.2885 & -0.5200 & 1.3871 & 0.8022 & 0.0740 & 0.7311 \\
$\mathrm{rm}_{t}$ & -5.6579 & -2.6535 & 1.6906 & 1.3674 & 0.0369 & 0.5911 \\
$5 \%$ & -2.9780 & -1.9429 & 5.6510 & 3.1430 & 0.1460 & 0.4630
\end{tabular}

\begin{tabular}{lllllllll} 
& & & & & & & & \\
\cline { 5 - 7 } & $\operatorname{MZ} \alpha(\tau)$ & $\operatorname{MZ} t(\tau)$ & $\operatorname{MSB}(\tau)$ & $\operatorname{MPT}(\tau)$ & $\operatorname{MZ} \alpha(\mu)$ & $\operatorname{MZt}(\mu)$ & $\operatorname{MSB}(\mu)$ & $\operatorname{MPT}(\mu)$ \\
\hline$\pi_{t}$ & -8.7126 & -2.0251 & 0.2324 & 10.6904 & -0.8105 & -0.4695 & 0.5793 & 19.6167 \\
$i_{t}$ & -3.9295 & -1.3901 & 0.3538 & 23.0450 & -3.0664 & -1.2315 & 0.4016 & 7.9787 \\
$e_{t}$ & -33.1951 & -4.0672 & 0.1225 & 2.7838 & -9.9063 & -2.1876 & 0.2208 & 2.6248 \\
$\mathrm{rm}_{t}$ & -47.5004 & -4.8666 & 0.1025 & 1.9535 & -13.1135 & -2.4176 & 0.1844 & 2.4207 \\
$5 \%$ & 17.3000 & -2.9100 & 0.1680 & 5.4800 & -8.1000 & -1.9800 & 0.2330 & 3.1700
\end{tabular}

Notes: $\operatorname{ADF}(\tau), \operatorname{ADF}(\mu)$ and $\operatorname{ADF}$, are tests of the unit root null hypothesis where the test regression contains a constant and a trend, a constant and no deterministic components, respectively. A similar notational convention is followed for the DFGLS and Ng-Perron tests. KPSS tests of stationarity around a non-zero mean and a linear trend are displayed as $\eta_{\tau}$ and $\eta_{\mu}$.

Using EViews5, we conduct several unit root tests prior to testing for multivariate cointegration. We assume a unit root process in each individual time series and also a common unit root for all the variables together. Applying the ADF (augmented Dickey-Fuller), ${ }^{13}$ and Phillips-Perron (PP) ${ }^{14}$ tests to our time series results in failure to reject the null hypothesis of non-stationarity at

\footnotetext{
13 Dickey and Fuller (1979); Dickey and Fuller (1981).

14 Perron (1988); Phillips (1987); and Phillips and Perron (1988).
} 
the $5 \%$ level for the inflation and the interest rate while the exchange rate and real money balances series seem to be stationary. But when following Dejong et al. (1992), we used Elliot et al. (1996) (ERS) test, generalized least squares (GLS) local detrending, the $\mathrm{Ng}$ and Perron (2001) and the Kwiatkowski et al. (1992) (KPSS) tests, stationarity of the series are not supported especially not by the KPSS tests, and this includes the exchange rate and real money balances.

Given the integrated nature of the time series, we test whether there exists a cointegrated relation between the variables. Before we test and identify the cointegrating relation, we check whether the theoretical relation postulated in Section 3 is true statistically in a general unrestricted vector autoregression (VAR) model. Granger causality/block exogeneity Wald tests seem to confirm that the inflation rate, exchange rate, and real money balances do explain changes in the interest rate, not the other way round, supporting the theoretical framework. Assuming all the variables as endogenous, the Wald test does not reject that the other three variables can be treated as exogenous in an interest rate equation. ${ }^{15}$ Given the direction of this causation, we will examine in the next section the sign and magnitude of the impact of these variables on the interest rate.

\subsection{The cointegration relation}

We first test to verify whether there is a cointegrating relationship between the four variables for the full sample using the Johansen (1988) maximum likelihood method in EViews5. We find the existence of two cointegrating relations using a linear model (with intercept). The presence of two cointegrating vectors has also been checked with alternate assumptions.

A visual inspection of Fig. 1 indicates that the variables appear to have structurally changed. Such apparent changes in the time series process can result from events such as financial crisis: August 1998 in the case of Russia or significant changes in government policies such as a change of regime from money to exchange rate stabilisation programme (Hamilton, 1996). Therefore, for the outlier in Fig. 1 in 1998, we have added a dummy as an exogenous variable in the cointegration space to overcome the normality problem in the data generating process.

The Trace test in Table 2 indicates the existence of two cointegrating relations and we have identified the first relation to be an interest rate rule and the second vector to be an inflation equation by imposing four non-binding restrictions.

The trace statistics (LR test) indicate two cointegrating equations at $1 \%$ significance level. The fact that the null $r=1$ is rejected at a $1 \%$ significance level means that there exists two meaningful long-run relationships between the interest rate, inflation, the exchange rate, and the real money balances. Further, one endogenous variable representing a monetary policy reaction function is the interest rate, and the other variable has been identified to be inflation by imposing unit restriction on the inflation coefficient. Therefore, the normalized cointegrating equation obtained from Johansen test in Table 2 can be written as:

$$
\begin{aligned}
& i_{t}=-27.37+\pi_{t}+\underset{(2.505)}{4.286 e_{t}}+\underset{(1.447)}{8.439 m_{t}} \\
& \pi_{t}=-14.00+\underset{(1.269)}{1.189 e_{t}+7.129 m_{t}}
\end{aligned}
$$

Figures in the parentheses under the estimated normalized coefficient are $t$-values. While the exchange rate has significantly influenced interest rate in the first long-run relation with inflation

\footnotetext{
15 The detailed test results could be obtained from the authors.
} 
Table 2

Johansen cointegration test results

\begin{tabular}{|c|c|c|c|c|}
\hline Hypothesized no. of CE(s) & Eigen value & Trace statistic & 0.05 Critical value & Probability** \\
\hline \multicolumn{5}{|c|}{ 1. Unrestricted cointegration rank test (trace) } \\
\hline None* & 0.245 & 73.785 & 47.856 & 0.000 \\
\hline At most $1^{*}$ & 0.112 & 31.987 & 29.797 & 0.0047 \\
\hline At most 2 & 0.090 & 14.221 & 15.495 & 0.072 \\
\hline \multirow[t]{2}{*}{ At most 3} & 0.001 & 0.198 & 3.841 & 0.6399 \\
\hline & & \multicolumn{3}{|c|}{ Max-Eigen statistic } \\
\hline \multicolumn{5}{|c|}{ 2. Unrestricted cointegration rank test (maximum Eigen value) } \\
\hline None* & 0.245 & 41.798 & 27.584 & 0.0002 \\
\hline At most $1^{*}$ & 0.112 & 17.767 & 21.132 & 0.023 \\
\hline At most 2 & 0.090 & 14.022 & 14.265 & 0.051 \\
\hline At most 3 & 0.001 & 0.198 & 3.841 & 0.640 \\
\hline
\end{tabular}

Notes: Sample (adjusted): from 1992M12 to 2005M01; included observations: 146 after adjustments; trend assumption: linear deterministic trend; series: REFRATEM, DLCPISA, LERATE, LRM; exogenous series: D98; lags interval (in first differences): $1-5$; trace test indicates two cointegrating equations at the 0.05 level; $\left(^{*}\right)$ denotes rejection of the hypothesis at the 0.05 level; $\left(^{* *}\right)$ MacKinnon-Haug-Michelis (1999), $p$-values.

having a unit coefficient, the real money growth has significantly contributed to a rise in inflation in the second cointegrating equation. The second long-run relation, identified to be an inflation equation, shows that the exchange rate is insignificant in driving inflation for the entire sample. This is in line with the earlier findings in the context of Russia, in the sense that the monetary aggregates have been the key factor determining inflation (see, for example, Esanov et al., 2004). The signs of the coefficients turned out to be as per the apriori expectation in Eq. (6). But real money supply, not being significant in the interest rate equation, implies that for the entire sample period, exchange rate appears to have driven interest rate policy. This leads us to test for a possible structural break in 1998, as the fixed exchange rate regime was abandoned giving rise to a significant devaluation. A CHOW test does reveal a breakpoint in 1998 and the null hypothesis of no structural break is rejected (Table 3). Also, the cumulative sum of the squared residuals, indicate a clear break point in 1998 (see Fig. 2).

Given the break in 1998, we estimated for possible cointegration for the first sub-sample (1992-1998), and found two long-run relations and identified them as interest rate and inflation relations by imposing the same non-binding restrictions. Both exchange rate and real money turned out to be the driving factors in interest rate and inflation determination, as both the variables are significant as given in the equation below.

$$
\begin{gathered}
i_{t}=73.695+\pi_{t}-\underset{(4.214)}{6.189 e_{t}-29.454 m_{t}} \\
\pi_{t}=53.612-10.244 e_{t}-15.539 m_{t} \\
(10.482)
\end{gathered}
$$

Table 3

Test for structural break $\left(H_{0}=\right.$ no structural break in 1998)

Chow forecast test: forecast from 1998M05 to 2005M01

\begin{tabular}{llll}
\hline$F$-statistic & 1.667524 & Probability: $F(81,40)$ & 0.038214 \\
Log likelihood ratio & 219.9692 & Probability: Chi-square (81) & 0.000000 \\
\hline
\end{tabular}




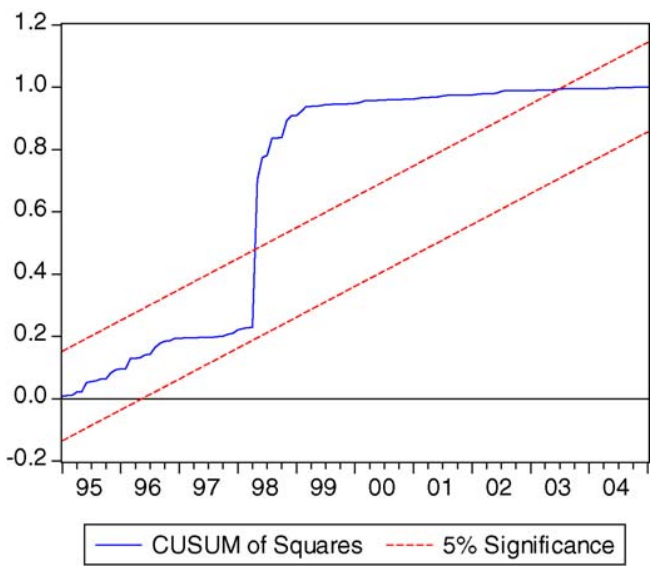

Fig. 2. Cumulative sum of squared recursive residuals.

But the signs of the coefficients associated with exchange rate and real money are negative, suggesting that with the increase in real money balances, nominal interest rate has declined in the long-run, and given a fixed exchange rate regime during this period, the decline in the interest rate does explain the negative sign. From this sub-period long-run relation, we can infer that in the second sub-sample (or in the recent years) exchange rate changes have been the driving force behind interest rate determination as reflected in the estimates for the whole sample (Eq. (7)). Overall it suggests that there is a need to target inflation so as to eliminate inflation persistence, which is possibly occurring as a result of high money growth generating the expectation of currency depreciation in the recent years.

Whether the interest rate responds more to currency depreciation as opposed to inflation is hard to say from these long-run results. The coefficients - whether high or low - do not say anything about the influence of the respective variables. In order to examine the dominant effect of these variables, we need to formulate a short-run model, where shocks to the respective variables on the changes in the interest rate can be seen over a time horizon.

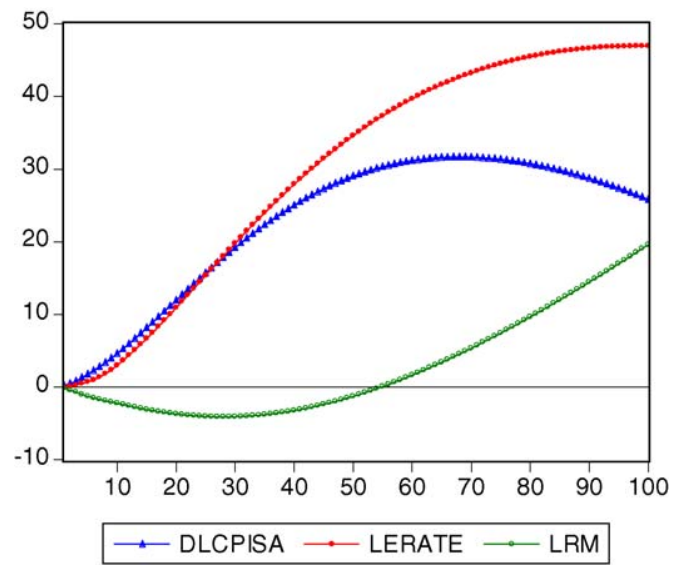

Fig. 3. Accumulated impulse response of REFRATEM to generalized 1 S.D. innovations. 
Table 4

Vector Error Correction Model

\begin{tabular}{|c|c|c|c|c|}
\hline Error correction & D(REFRATEM) & D(DLCPISA) & D(LERATE) & $\mathrm{D}(\mathrm{LRM})$ \\
\hline CointEq1 & $\begin{array}{c}-0.0679 \\
{[-4.4201]}\end{array}$ & $\begin{array}{c}0.0746 \\
{[2.6354]}\end{array}$ & $\begin{array}{c}0.0009 \\
{[0.1031]}\end{array}$ & $\begin{array}{c}-0.0007 \\
{[-1.1527]}\end{array}$ \\
\hline CointEq2 & $\begin{array}{c}0.0657 \\
{[2.4882]}\end{array}$ & $\begin{array}{c}-0.1981 \\
{[-4.0765]}\end{array}$ & $\begin{array}{c}0.0021 \\
{[1.3426]}\end{array}$ & $\begin{array}{c}-0.0003 \\
{[-0.2565]}\end{array}$ \\
\hline D(REFRATEM(-1)) & $\begin{array}{c}-0.1954 \\
{[-2.7141]}\end{array}$ & $\begin{array}{c}0.2825 \\
{[2.1298]}\end{array}$ & $\begin{array}{c}-0.0097 \\
{[-2.2474]}\end{array}$ & $\begin{array}{c}-0.0027 \\
{[-0.8957]}\end{array}$ \\
\hline D(REFRATEM(-2)) & $\begin{array}{c}-0.0242 \\
{[-0.3200]}\end{array}$ & $\begin{array}{c}0.2529 \\
{[1.8143]}\end{array}$ & $\begin{array}{c}-0.0104 \\
{[-2.2858]}\end{array}$ & $\begin{array}{c}-0.0053 \\
{[-1.6479]}\end{array}$ \\
\hline D(REFRATEM(-3)) & $\begin{array}{c}0.0281 \\
{[0.3693]}\end{array}$ & $\begin{array}{c}-0.1984 \\
{[-1.4162]}\end{array}$ & $\begin{array}{c}-0.0073 \\
{[-1.6002]}\end{array}$ & $\begin{array}{c}-0.0019 \\
{[-0.5852]}\end{array}$ \\
\hline D(REFRATEM(-4)) & $\begin{array}{c}0.0101 \\
{[0.1333]}\end{array}$ & $\begin{array}{c}-0.0852 \\
{[-0.6082]}\end{array}$ & $\begin{array}{c}0.0331 \\
{[7.2567]}\end{array}$ & $\begin{array}{c}-0.0045 \\
{[-1.3947]}\end{array}$ \\
\hline D(REFRATEM $(-5))$ & $\begin{array}{c}-0.1458 \\
{[-1.6459]}\end{array}$ & $\begin{array}{c}1.0083 \\
{[6.1816]}\end{array}$ & $\begin{array}{c}-0.0011 \\
{[-0.2171]}\end{array}$ & $\begin{array}{c}-0.0104 \\
{[-2.7943]}\end{array}$ \\
\hline $\mathrm{D}(\mathrm{DLCPISA}(-1))$ & $\begin{array}{c}-0.1160 \\
{[-2.1971]}\end{array}$ & $\begin{array}{c}-0.2375 \\
{[-2.4419]}\end{array}$ & $\begin{array}{c}0.0003 \\
{[0.0862]}\end{array}$ & $\begin{array}{c}-0.0042 \\
{[-1.8937]}\end{array}$ \\
\hline $\mathrm{D}(\operatorname{DLCPISA}(-2))$ & $\begin{array}{c}-0.0822 \\
{[-1.5026]}\end{array}$ & $\begin{array}{c}-0.0888 \\
{[-0.8814]}\end{array}$ & $\begin{array}{c}0.0032 \\
{[0.9914]}\end{array}$ & $\begin{array}{c}-0.0044 \\
{[-1.9143]}\end{array}$ \\
\hline D(DLCPISA(-3)) & $\begin{array}{c}-0.0248 \\
{[-0.4662]}\end{array}$ & $\begin{array}{c}-0.0843 \\
{[-0.8608]}\end{array}$ & $\begin{array}{c}-0.0033 \\
{[-1.0248]}\end{array}$ & $\begin{array}{c}0.0004 \\
{[0.1920]}\end{array}$ \\
\hline $\mathrm{D}(\mathrm{DLCPISA}(-4))$ & $\begin{array}{c}-0.0312 \\
{[-0.7187]}\end{array}$ & $\begin{array}{c}-0.0120 \\
{[-0.1505]}\end{array}$ & $\begin{array}{c}0.0013 \\
{[0.4965]}\end{array}$ & $\begin{array}{c}0.0019 \\
{[1.0161]}\end{array}$ \\
\hline D(DLCPISA $(-5))$ & $\begin{array}{c}-0.0183 \\
{[-0.5953]}\end{array}$ & $\begin{array}{c}0.0812 \\
{[1.4299]}\end{array}$ & $\begin{array}{c}0.0012 \\
{[0.6730]}\end{array}$ & $\begin{array}{c}-0.0015 \\
{[-1.1204]}\end{array}$ \\
\hline D(LERATE $(-1))$ & $\begin{array}{c}2.2731 \\
{[1.6558]}\end{array}$ & $\begin{array}{l}18.2269 \\
{[7.2086]}\end{array}$ & $\begin{array}{c}0.4847 \\
{[5.8825]}\end{array}$ & $\begin{array}{c}-0.1410 \\
{[-2.4381]}\end{array}$ \\
\hline $\mathrm{D}(\operatorname{LERATE}(-2))$ & $\begin{array}{c}-0.7876 \\
{[-0.4685]}\end{array}$ & $\begin{array}{c}-8.4336 \\
{[-2.7235]}\end{array}$ & $\begin{array}{c}-0.1759 \\
{[-1.7433]}\end{array}$ & $\begin{array}{c}0.0693 \\
{[0.9788]}\end{array}$ \\
\hline D(LERATE $(-3))$ & $\begin{array}{c}-0.1450 \\
{[-0.0879]}\end{array}$ & $\begin{array}{c}5.7808 \\
{[1.9036]}\end{array}$ & $\begin{array}{c}0.1713 \\
{[1.7305]}\end{array}$ & $\begin{array}{c}0.0356 \\
{[0.5128]}\end{array}$ \\
\hline $\mathrm{D}(\operatorname{LERATE}(-4))$ & $\begin{array}{c}-2.0973 \\
{[-1.4467]}\end{array}$ & $\begin{array}{c}6.5665 \\
{[2.4591]}\end{array}$ & $\begin{array}{c}0.1890 \\
{[2.1725]}\end{array}$ & $\begin{array}{c}-0.1439 \\
{[-2.3561]}\end{array}$ \\
\hline D(LERATE $(-5))$ & $\begin{array}{c}-0.2045 \\
{[-0.1457]}\end{array}$ & $\begin{array}{c}4.4612 \\
{[1.7262]}\end{array}$ & $\begin{array}{c}-0.3045 \\
{[-3.6160]}\end{array}$ & $\begin{array}{c}-0.1851 \\
{[-3.1309]}\end{array}$ \\
\hline $\mathrm{D}(\operatorname{LRM}(-1))$ & $\begin{array}{c}-3.6995 \\
{[-1.6086]}\end{array}$ & $\begin{array}{c}-1.0892 \\
{[-0.2571]}\end{array}$ & $\begin{array}{c}0.0595 \\
{[0.4313]}\end{array}$ & $\begin{array}{c}0.0114 \\
{[0.1181]}\end{array}$ \\
\hline $\mathrm{D}(\operatorname{LRM}(-2))$ & $\begin{array}{c}1.4119 \\
{[0.6314]}\end{array}$ & $\begin{array}{c}6.9647 \\
{[1.6909]}\end{array}$ & $\begin{array}{c}-0.1706 \\
{[-1.2711]}\end{array}$ & $\begin{array}{c}0.0841 \\
{[0.8922]}\end{array}$ \\
\hline $\mathrm{D}(\operatorname{LRM}(-3))$ & $\begin{array}{c}0.5792 \\
{[0.2589]}\end{array}$ & $\begin{array}{c}8.7496 \\
{[2.1238]}\end{array}$ & $\begin{array}{c}0.0800 \\
{[0.5960]}\end{array}$ & $\begin{array}{c}-0.0543 \\
{[-0.5763]}\end{array}$ \\
\hline $\mathrm{D}(\operatorname{LRM}(-4))$ & $\begin{array}{c}-0.6323 \\
{[-0.2984]}\end{array}$ & $\begin{array}{c}0.8699 \\
{[0.2229]}\end{array}$ & $\begin{array}{c}-0.1553 \\
{[-1.2212]}\end{array}$ & $\begin{array}{c}-0.0107 \\
{[-0.1199]}\end{array}$ \\
\hline
\end{tabular}


Table 4 (Continued)

\begin{tabular}{|c|c|c|c|c|}
\hline Error correction & D(REFRATEM) & D(DLCPISA) & D(LERATE) & $\mathrm{D}(\mathrm{LRM})$ \\
\hline $\mathrm{D}(\mathrm{LRM}(-5))$ & $\begin{array}{c}0.8495 \\
{[0.4056]}\end{array}$ & $\begin{array}{c}8.2819 \\
{[2.1471]}\end{array}$ & $\begin{array}{c}0.1574 \\
{[1.2522]}\end{array}$ & $\begin{array}{c}-0.2727 \\
{[-3.0904]}\end{array}$ \\
\hline$C$ & $\begin{array}{c}-0.1071 \\
{[-0.8629]}\end{array}$ & $\begin{array}{c}-1.0426 \\
{[-4.5590]}\end{array}$ & $\begin{array}{c}0.0203 \\
{[2.7198]}\end{array}$ & $\begin{array}{c}0.0121 \\
{[2.3128]}\end{array}$ \\
\hline D98 & $\begin{array}{c}5.4535 \\
{[7.3702]}\end{array}$ & $\begin{array}{c}-0.1836 \\
{[-0.1347]}\end{array}$ & $\begin{array}{c}-0.0170 \\
{[-0.3836]}\end{array}$ & $\begin{array}{c}0.0201 \\
{[0.6453]}\end{array}$ \\
\hline$R$-squared & 0.4275 & 0.7676 & 0.5723 & 0.4968 \\
\hline Adj. $R$-squared & 0.3221 & 0.7248 & 0.4935 & 0.4043 \\
\hline Sum sq. resides & 130.8850 & 444.0158 & 0.4715 & 0.2324 \\
\hline S.E. equation & 1.0233 & 1.8847 & 0.0614 & 0.0431 \\
\hline$F$-statistic & 4.0576 & 17.9489 & 7.2709 & 5.3667 \\
\hline Log likelihood & -201.7646 & -292.7694 & 217.3753 & 270.0886 \\
\hline Akaike AIC & 3.0304 & 4.2519 & -2.5956 & -3.3032 \\
\hline Schwarz SC & 3.5142 & 4.7358 & -2.1118 & -2.8193 \\
\hline Mean dependent & -0.0375 & -0.0638 & 0.0328 & 0.0005 \\
\hline S.D. dependent & 1.2428 & 3.5928 & 0.0863 & 0.0559 \\
\hline Determinant resid covariance (dof adj.) & & 0.0001 & & \\
\hline Determinant resid covariance & & 0.0000 & & \\
\hline Log likelihood & & 16.7488 & & \\
\hline Akaike information criterion & & 1.1712 & & \\
\hline Schwarz criterion & & 3.2679 & & \\
\hline
\end{tabular}

Notes: Sample (adjusted): 1992M09 to 2005M01; included observations: 149 after adjustments; $t$-statistics in [].

\subsection{Deviations from the long-run equilibrium}

The observation, that the interest, inflation and exchange rates are integrated series, suggests that the short-term dynamic behaviour of the Russian economy can be observed within an errorcorrection model. Such a model is described by:

$$
\begin{aligned}
& \Delta i_{t}=\beta_{01} z_{t-1}+\sum \beta_{i} \Delta i_{t-i}+\sum \gamma_{i} \Delta \pi_{t-i}+\sum \delta_{i} \Delta e_{t-i}+\sum \phi_{i} \Delta m_{t-i}+u_{t}, \\
& \Delta \pi_{t}=\beta_{02} z_{t-1}+\sum \beta_{i} \Delta i_{t-i}+\sum \gamma_{i} \Delta \pi_{t-i}+\sum \delta_{i} \Delta e_{t-i}+\sum \phi_{i} \Delta m_{t-i}+u_{t}, \\
& \Delta e_{t}=\beta_{03} z_{t-1}+\sum \beta_{i} \Delta i_{t-i}+\sum \gamma_{i} \Delta \pi_{t-i}+\sum \delta_{i} \Delta e_{t-i}+\sum \phi_{i} \Delta m_{t-i}+u_{t}, \\
& \Delta m_{t}=\beta_{04} z_{t-1}+\sum \beta_{i} \Delta i_{t-i}+\sum \gamma_{i} \Delta \pi_{t-i}+\sum \delta_{i} \Delta e_{t-i}+\sum \phi_{i} \Delta m_{t-i}+u_{t}
\end{aligned}
$$

where $z_{t}$ is the residual/error correction term of the cointegration relation (CR).

From Table 4, the short-run adjustment coefficient (CR1) associated with interest rates suggest that the interest rates have been adjusted by $6.8 \%$ during the sample period due to changes in the variables included in the long-run relation. With regard to the adjustment coefficient of inflation, the inflation rate has adjusted at the rate of $19.8 \%$ and significant. The adjustment coefficient associated with the other two variables, are not significant, suggesting that they do not adjust, and hence they are truly exogenous. Turning to the dynamics of other variables, past interest rate, exchange rate, and money supply changes do significantly influence inflation in 
the short-run. With regard to the exchange rate, as the interest rate increases, the exchange rate appreciates and this coefficient is significant. Past inflation rates and past money growth rates do not have significant effect on the short-run changes in exchange rate. Overall, in the short-run the interest rate adjustment has been slow, while inflation adjustment has been relatively faster reacting significantly to changes in interest rate, exchange rate and money growth. Interest rate and exchange rate changes also have significant effect on real money growth in the short-run.

Because of the mixed picture resulting from different lagged variables in the short-run, we undertook a generalised impulse response analysis using the short-run model, which is presented in Fig. 3. The figure analyses the response of the interest rate to a one standard deviation shock to the other variables. Fig. 3 shows that the short-run impact of the exchange rate on changes in the interest rate is more prominent over a longer period, as opposed to the impact of inflation, which dies out after 10 months. The muted long-run impact of inflation on interest rate appears to reflect that the Bank of Russia does not use the interest rate to stabilise inflation.

\section{Conclusion}

This paper investigates the relation between the interest rate, inflation rate, exchange rate, and money supply in Russia since 1992. We have shown that the interest rate has responded more to changes in the exchange rate than to inflation. Whereas, in the long-run inflation determined interest rates, we have shown that in the short-run, nominal interest rate has negatively reacted to inflation, whereas inflation reacts positively to interest rate. Using an error-correction mechanism we find that, similar to Mishkin (1992), the short-run adjustment of interest rates to inflation, exchange rate, and money growth is very slow, only at the rate of $6.8 \%$. This suggests that the interest rate is not targeted by the central bank as a direct instrument of monetary control. This is not surprising in economies in transition and especially in Russia where the mechanisms of monetary transmission and financial intermediation took long periods to be put in place and are still in need of reform and regulation. From the starting point where credits were channelled to state-owned enterprises through state-owned banks, a long road would always have to be travelled before interest rates became a proper indicator of monetary policy. Moreover, the 1998 default and devaluation undermined the progress accomplished since 1996 in the banking sector and capital market in general.

Given the apparent trade-off between inflation and exchange rate, the central bank could move to a flexible inflation targeting type of monetary policy framework, where the interest rate could be used as a direct instrument of monetary control. Relevant studies highlight the challenges of a successful move to inflation targeting, but the central banks of the Czech Republic, Hungary and Poland have all achieved such a move. ${ }^{16}$ In the case of those countries, this policy shift was driven by the obligatory conditionality for EMU accession. But for Russia's interest, the concern is that intervention in the foreign exchange market may hinder the credibility of monetary policy, because the public may realize that stabilizing the exchange rate takes precedence over promoting price stability as a policy objective. ${ }^{17}$ We therefore conclude that Russia should adopt a pre-announced inflation target which would coordinate expectations and thus generate a more stable inflation scenario for the economy.

\footnotetext{
16 See Jonas and Mishkin, 2003.

17 See Mishkin (2000).
} 


\section{Acknowledgement}

We are grateful to the participants of the Conference 'Transition in the CIS: Achievements and New Challenges', organised by the Institute for the Economy in Transition, the US Agency for International Development and the Academy of National Economy, held in Moscow on 13-14 September 2004. We are also grateful to the participants of the "Second Meeting of the UACES Study Group on Monetary Policy in Selected CIS countries", held in Helsinki on February 10-11, 2005, and to our discussant Zbigniew Polanski, NBP, Warsaw, Poland. We have also benefited from comments by Christopher Granville, Mark Holmes, Mariusz Jamuzek, Tomas Kogel, Simon Mohun, Theo Panagiotidis, and Eric Pentecost. All errors are our own.

\section{References}

Barro, R.J., Gordon, D.B., 1983. Rules, discretion and reputation in a model of monetary policy. J. Monet. Econ. 12, 101-121.

Barsky, R., 1987. The Fisher hypothesis and the forecastability and persistence of inflation. J. Monet. Econ. 19, 3-24.

Basdevant, O., 2000. An econometric model of the Russian federation. Econ. Model. 17 (2), 305-336.

Basdevant, O., Hall, S.G., 2002. The 1998 Russian crisis: could the exchange rate volatility have predicted it? J. Policy Model. 24 (2), 151-168.

Bernanke, B., Laubach, T., et al., 1999. Inflation Targeting: Lessons from the International Experience. Princeton University Press, Princeton.

Buch, C., 1998. Russian monetary policy_assessing the track record. Econ. Syst. 22 (2).

Choudhry, T., 1998. Another visit to the Cagan model of money demand: the latest Russian experience. J. Int. Money Finance 17 (2), 355-376.

Clarida, R., Gali, J., et al., 1999. The science of monetary policy: a new Keynesian perspective. J. Econ. Lit. 37 (4), 1661-1707.

Cotarelli, C., Doyle, P., 1999. Disinflation in Transition 1993-1997, IMF Occasional Paper, 179.

Crowder, W.J., Hoffman, D.L., 1996. The long-run relationship between nominal interest rates and inflation: the Fisher equation revisited. J. Money Credit Bank. 28 (1), 102-118.

Dejong, D.N., Nankervis, J.C., Nsavin, E., Whiteman, C.H., 1992. Integration versus trend stationarity in time series. Econometrica 60 (2), 423-433.

Desai, P., 2000. Why did the Rouble collapse in August 1998? Am. Econ. Rev. Papers Proc. 90 (2), 48-52.

Dickey, D.A., Fuller, W.A., 1979. Distribution of the estimators for autoregressive time-series with a unit root. J. Am. Stat. Assoc. 74, 427-431.

Dickey, D.A., Fuller, W.A., 1981. Likelihood ratio statistics for autoregressive time series with a unit root. Econometrica 55, 251-276.

Elliot, G., Rothenberg, T.J., Stock, J.H., 1996. Efficient tests for an autoregressive unit root. Econometrica 64, $813-836$.

Esanov, A., Merkl, C., Vinhas de Souza, L., 2004. Monetary Policy Rules for Russia. BOFIT Discussion Papers No. 11, Bank of Finland, Helsinki.

Evans, M.D., Lewis, K.K., 1995. Do expected shifts in inflation affect estimates of the long-run Fisher relation? J. Finance 50 (1), 225-253.

Frenkel, J., Taylor, M.P., 1993. Money demand and inflation in Yugoslavia, 1980-1989. J. Macroecon. 15, $455-481$.

Goskomstat, R.F., 1992-2004. Sotsial'no-ekonomicheskoe polozhenoe Rossiskoi Federatsii (Socio economic situation of Russia). Moscow, various issues.

Granger, C.W.J., 1986. Developments in the study of cointegrated economic variables. Oxford Bull. Econ. Stat. 48, $213-228$.

Granville, B., 2001. The Problem of Monetary Stabilisation. In: Granville, B., Oppenheimer, P. (Eds.), Russia’s PostCommunist Economy. Oxford University Press, Oxford, pp. 93-130.

Granville, B., 2002. The IMF and the Ruble zone: response to Odling-Smee and Pastor. Comparat. Econ. Stud. XLIV (4), 59-80.

Granville, B., 2003. Taxation of financial intermediaries as a source of budget revenue: Russia in the 1990s. In: Honohan, P. (Ed.), Taxation of Financial Intermediation, Theory and Practice for Emerging Economies. World Bank and Oxford University Press, Washington, DC, New York, pp. 269-288. 
Hamilton, J.D., 1996. Time Series Analysis. Princeton University Press, Princeton, NJ.

Johansen, S., 1988. Statistical analysis of cointegrating vectors. J. Econ. Dynam. Contr. 12, 231-254.

Jonas, J., Mishkin, F.S., 2003. Inflation targeting in transition countries: experience and prospects. NBER Working Paper No. 9667, April.

Kharas, H.J., Pinto, B., et al., 2001. An analysis of Russia's 1998 meltdown: fundamentals and market signals. Brookings Pap. Econ. Act. 1, 1-68.

Komulainen, T., Pirtilla, J., 2000. Fiscal explanations for inflation: any evidence from transition economies? BOFIT, Discussion Papers 11.

Korhonen, I., 1998. A Vector Error Correction Model for prices, money, output, and interest rate in Russia, Bank of Finland. Rev. Econ. Transit. 5, 33-44.

Kwiatkowski, D., Phillips, P.C.B., et al., 1992. Testing the null hypothesis of stationarity against the alternative of a unit root: how sure are we that economic time series have a unit root? J. Econ. 54, 159-178.

Kwon, G., Ohnsorge, F., Oomes, N., Lall, S., Madrid, P., Spilimbergo, A., Teo, L., 2004. Russian Federation, Selected Issues. IMF Country Report No. 04/316, IMF: 10-42.

Mishkin, F.S., 1992. Is the Fisher effect for real? A re-examination of the relationship between inflation and interest rates. J. Monet. Econ. 30 (2), 195-215.

Mishkin, F.S., 2000. Inflation targeting in emerging-market countries. Am. Econ. Rev. Pap. Proc. 90 (2), $105-109$.

$\mathrm{Ng}$, S., Perron, P., 2001. Lag length selection and the construction of unit root test with good size and power. Econometrica 69, 1519-1554.

Nikolic, M., 2000. Money growth-inflation relationship in postcommunist Russia. J. Compar. Econ. 28 (1), $108-133$.

OECD, 2004. OECD Economic Surveys: Russian Federation. Organisation for Economic Co-operation and Development, Paris, France, May.

Orlowski, L.T., 2000. Direct inflation targeting in Central Europe. Post Sov. Geogr. Econ. 41 (2), 134-154.

Papazoglou, C., Pentecost, E., 2004. The dynamic adjustment of a transition economy in the early stages of transformation. J. Macroecon. 26 (3), 547-561.

Perron, P., 1988. Trends and random walks in macroeconomic time series. J. Econ. Dynam. Contr. 12, $297-332$.

Phillips, P.C.B., 1987. Time series regressions with a unit root. Econometrica 55, 277-301.

Phillips, P.C.B., Perron, P., 1988. Testing for a unit root in time series regression. Biometrika 75, 335-346.

Pinto, B., Gurvich, E., et al., 2004. Lessons from the Russian crisis of 1998 and recovery. Managing volatility and crises: a practitioner's guide overview. In: Aizenman, J., Pinto, B. World Bank, Washington, DC. February (draft), available on: http://www1.worldbank.org/economicpolicy/mv/mvcguide.html.

Svensson, L.E.O., 1999. Inflation targeting as a monetary policy rule. J. Monet. Econ. 43, 607-654.

Taylor, J.B., 2001. The role of the exchange rate in monetary policy rules. Am. Econ. Rev. Pap. Proc. 91 (2), $263-267$.

Taylor, M.P., 1991. The hyperinflation model of money demand revisited. J. Money Credit Bank. 23, 327-351. 